\title{
Angels among us? The Watchers myth and angelology in Ephrem's Commentary on Genesis and the Ethiopic tradition
}

Journal for the Study of the Pseudepigrapha

(c) The Author(s) 2019

Article reuse guidelines: sagepub.com/journals-permissions DOI: $10.1177 / 0951820719875716$ journals.sagepub.com/home/jsp

\section{David A Skelton}

Pepperdine University, USA

\begin{abstract}
This study examines the euhemeristic interpretation of Genesis 6:1-4 as it appears in Ephrem of Nisibis' Commentary on Genesis and its influence on Syriac and Ethiopic commentary traditions. I suggest that Ephrem's attempt to mitigate the angelic interpretation of Genesis 6 ironically mirrors his own angelology. The distinctive components he adds to the Watchers myth (different geography, diet, and bodies) are central virtues in Ephrem's attempt to make virginity and monasticism ideals for all Christians. For Ephrem, the angels are paradigms of these ideals, and those who achieve them become equal to the angels. Surprisingly, these distinctive components reappear in the Ethiopian commentary tradition on Genesis (andemta), but unlike Ephrem, the andemta makes the equation of Sethites with angels and monks quite explicit. Overall, this analysis between Ephrem and the andemta reveals the influence of Syriac interpretation on the Ethiopian commentary tradition as well as the centrality of angelology in the Sethite reading of Genesis 6:1-4.
\end{abstract}

\section{Keywords}

angels, Ephrem, Ethiopic, Sethites, Syriac, Watchers myth

\section{Introduction}

One of the earliest denials of the equation of the "sons of God" with angels in Genesis 6 comes from the Syriac writer Ephrem of Nisibis (306-373 CE). Although Ephrem denies this equation throughout his literature and often castigates those who hold it, his lengthiest rebuttal comes in his Commentary on Genesis where he not only rejects

\footnotetext{
Corresponding author:

David A Skelton, Pepperdine University, 24255 Pacific Coast Hwy, Malibu, CA 90263-3999, USA.

Email: david.skelton@pepperdine.edu
} 
the angelic interpretation of Genesis 6 but also sets up a counter narrative that re-signifies many of the key components of the Watchers myth known from several Jewish and Christian sources, most notably 1 Enoch 6-11. It is the purpose of this paper to examine Ephrem's re-telling of this myth in order to explore his countering of a myth that he deems heretical with another myth. In particular, why does his counter myth have several vestiges of the original, and what relationship does Ephrem's re-telling of the myth have to do with his overall theology and political ideology? Even though Ephrem rejects the angelic interpretation of Genesis 6, I will suggest that his own angelology, particularly Ephrem's accentuation of angels' paradigmatic role for ideal Christian behavior, influences his re-telling and re-signification of the Watchers myth. Although this angelic and monastic interpretation of Genesis 6:2 is implicit in Ephrem, I will contend it becomes prominent in later commentaries and apocryphal stories in Syriac and Ethiopic traditions by examining the Sethite interpretation of Genesis 6:2 in the andemta and the possible Syriac influences on this modern Ethiopic commentary tradition.

\section{The Watchers myth in Ephrem's time period}

The classic telling of the Watchers myth occurs in 1 Enoch 6-11, which is known in Greek in two different recensions, Ge'ez, and Aramaic fragments among the Dead Sea Scrolls. ${ }^{1}$ In this myth, there are two strands that have been combined into one story. ${ }^{2}$ The first and earliest strand is the Shemihazah myth $(6: 1-7: 1 \mathrm{c} ; 7: 2-6 ; 9: 1-5 ; 9: 7-8 \mathrm{~b}$; $9: 9-10: 3 ; 10: 9-11: 2)$. This myth refers to a coterie of angels led by Shemihazah who descend onto Mount Hermon and swear an oath to take the daughters of humanity for their wives. Their wives give birth to cannibalistic and carnivorous giants who bring destruction upon all the earth. There are three expansions to this myth in 7:1de, 9:8 cd, and 8:3, which refer to the teaching of sorcery, herbology, and astrology by Shemihazah and the other angels. The theme of forbidden knowledge also occurs in the second strand, centering around Asael (8:1-3, 9:6; and 10:4-8) who serves as a foil to Enoch and his heavenly revelations. ${ }^{3}$ In this tradition, Asael's teaching of metallurgy creates jewelry and weaponry and is the primary culprit for the violence that fills the earth. As a whole, this story blames the necessity for the Flood on two events: (1) the birth of giants, who are a product of illicit sex between humans and angels and (2) the teaching of esoteric knowledge.

The combination of angelic sex, cannibalistic giants, and esoteric knowledge also occurs in other versions of this myth that influenced both Jewish and Christian

1. For discussion of the Aramaic fragments of the Book of Watchers and the different versions of the Book of Enoch, cf. Józef T. Milik, The Books of Enoch: Aramaic Fragments of Qumran Cave 4 (Oxford: Clarendon Press, 1976), 22-40, 70-88; Siegbert Uhlig, Das äthiopische Henochbuch (JSHRZ, 5; Gütersloh: Gütersloher, 1984), 470-91; George W. E. Nickelsburg, 1 Enoch (Hermeneia; Minneapolis: Fortress, 2001), I, 9-20.

2. For the source criticism behind the Watchers myth, see Nickelsburg, 1 Enoch, I, 165-73 and Carol A. Newsom, "The Development of 1 Enoch 6-19: Cosmology and Judgment," CBQ 42 (1980): 310-29, esp. 313-22.

3. Newsom, "Development of 1 Enoch 6-19," 320-21. 
communities. ${ }^{4}$ In Jubilees (known among Christians as Little Genesis) and Homilies 8 in the Pseudo-Clementines (third to fourth century CE) the angels descend upon the earth for nobler reasons. ${ }^{5}$ Outside of the Pseudo-Clementine literature, it is difficult to know what version of this myth was known in Syria in Ephrem's time period. Though there are references to angelic sex and demonology in Jude, Justin, Tatian and the Acts of Thomas, the earliest reference to the Watchers myth in Syriac literature occurs in the work of Bardaisan (or his disciple) in the late second to early third century CE. ${ }^{6}$ In this text, Bardaisan uses the Watchers myth as an illustration, which suggests that it was well-known to his audience and predominant in certain Syriac communities. ${ }^{7}$

Despite the interrelation between Bardaisan and the Pseudo-Clementines and Ephrem's critique of Bardaisan in several works, he is most polemical against the version of the Watchers myth propagated by Manicheanism, which included a version of the Book of Giants. ${ }^{8}$ For example, in Hymn 7 of Contra Haereses, Ephrem belittles the

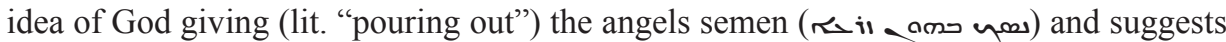
that there would not be space in the uterus for a child (roiv حidir ram was a giant. He even accuses Mani of confusing the Watchers myth and astrology, which makes sense in light of the fact that the fall of the Watchers became associated with the seduction of the archons in Manichaean literature. ${ }^{9}$ Even though the Ps.-Clem is more

4. For an overview of Enochic literature and Enochic themes in early Jewish literature, see Loren T. Stuckenbruck, "The 'Angels' and 'Giants' of Genesis 6:1-4 in Second and Third Century BCE Jewish Interpretation: Reflections on the Posture of Early Apocalyptic Traditions," DSD 7 (2000): 354-77. For an overview in early Christian literature, see James Vanderkam, "1 Enoch, Enoch Motifs, and Enoch in Early Christian Literature," in The Jewish Apocalyptic Heritage in Early Christianity (ed. James Vanderkam and William Adler; Minneapolis: Fortress, 1996), 33-101.

5. In Jubilees the angels descend in order to instruct humanity in uprightness before succumbing to temptation (4:15), and in the Ps.-Clem the angels desire to rebuke humanity's ingratitude and inadequate understanding of providence. For the dating of the Pseudo-Clementines, see Johannes Irmscher and Georg Strecker, "The Pseudo-Clementines," in New Testament Apocrypha (ed. Wilhelm Schneemelcher; Louisville: John Knox, 1992), II, 483-541.

6. Vanderkam, "1 Enoch, Enoch Motifs," 60-88.

7. In his Book of the Laws of Countries 12:22-25 Bardaisan suggests that God gave humanity more

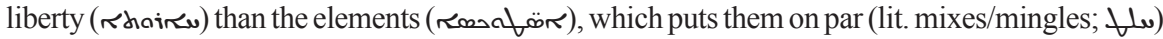
with angels. This statement leads him to contrast the angels' misuse of free-will via intercourse (م)iadurs) in Genesis 6:1-4 with humans who use it to serve God (14:1-8). The former brought about the fall of the Watchers from their position (_ambaïtre $\rightarrow$ a am Las), and the latter engendered exaltation and sanctification (ariotira csiditir) H. J. W. Drijvers, The Book of the Laws of Countries: Dialogue on Fate of Bardaisan of Edessa (Assen, Van Gorcum, 1965).

8. Ephrem's critique of Mani's teaching about giants also supports the view that Mani's Book of Giants was first written in a form of Syriac. For current research and a possible reconstruction of Mani's Book of Giants, see Enrico Murano, "New Research on Mani's Book of Giants," in Der östliche Manichäismus - Gattungs- und Werksgeschichte Vorträge des Göttinger Symposiums vom 4./5. März 2010 (ed. Zekine Özertural and Jens Wilkens; Berlin: de Gruyter, 2011), 100-11. Also, see J. C. Reeves, Jewish Lore in Manichaean Cosmogony: Studies in the Book of Giants Traditions (MHUC, 14; Cincinnati: Hebrew Union College Press, 1992). For the Book of Giants at Qumran, see Loren T. Stuckenbruck, The Book of Giants from Qumran: Texts, Translation, and Commentary (TSAJ, 63; Tübingen: Mohr Siebeck, 1997).

9. After his criticism of the Watchers myth, Ephrem boldly declares, 'Mani hated the truth and

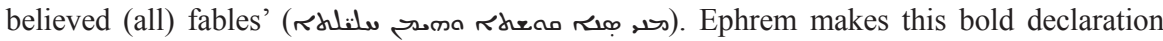


comfortable using the angelic aspect of the Watchers myth than Ephrem, it also uses the story to condemn astrology (Hom. 8:9-14) and like Ephrem, seems to do so because of Bardaisan and Manicheanism. ${ }^{10}$

If the Ps.-Clem literature utilized the angels in its critique of Bardaisan and Mani why was Ephrem against this interpretation of Genesis 6:1-4? Is it simply because he finds angel sex and giant babies ridiculous and unnatural or is there more to it? One possibility is Ephrem was simply following popular Jewish and Christian euhemeristic interpretations of this passage that were uncomfortable with humans having sex with angels. While Judaism had various strategies for discounting the angelic interpretation of the phrase "sons of God," many Christians favored reading this phrase as a reference to the "sons of Seth" (see below).$^{11}$ Ephrem follows the Christian reading strategy here, but his knowl-

because Mani 'affirmed (the narrative) concerning the giants and believed in the Chaldeans

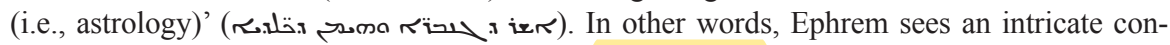
nection between Mani's myth of giants and his astrology For the text of Contra Haereses, see Edmund Beck, Des heiligen Ephraem des Syrers Hymn zz-c ontra Haereses (CSCO, 169-70// Scriptores Syri, 76-77; Louvain: Peeters, 1957). The Manicnaean text, Kephalaia 92:12-93:32 and the Syriac writer Theodore bar Koni (8th cent. CE) contain an account of the revolt of the Watchers that reference the archons and the descent of the abortions (Reeves, Jewish Lore, 71). For the Manichaean myth of the fall of the archons, see Geo Widengren, Mani and Manichaeism (trans. Charles Kessler; New York: Holt, Rinehart, and Winston, 1965), 56-57.

10. For the connection between Pseudo-Clementines and Mani, see Nicole Kelley, Knowledge and Religious Authority in the Pseudo-Clementines (Tübingen: Mohr Siebeck, 2006), 192204. Furthermore, Ephrem may not have made a fine distinction between the teachings of Mani, Bardaisan, and the Pseudo-Clementines. Ps.-Clem. quotes from Bardaisan (cf. BOLC 598 line 9ff and Rec 9.25.6-8), and alludes to the Book of Elchasaites, which is a Jewishapocalyptic group that inspired Mani's teachings. See Nicole Kelley, "Astrology in the Pseudo Clementine Recognitions," JEH 59 (2008): 607-29.

11. At roughly the same time, in the 5th century CE compilation, Genesis Rabbah, Rabbi Simeon b. Yohai interprets the phrase 'sons of God' (בני אלהים) as 'sons of judges' (בני (ביינא) and curses (מקלל) those who call humans sons of God (Gen. Rab. 26.5). Despite the problematic nature of dating rabbinic traditions, Trypho's echoing of this critique in the Dialogue with Trypho

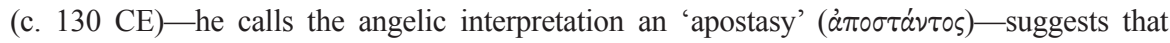
Rabbi Simeon b. Yohai's critique existed quite early in the Jewish community. Furthermore, Targums Onkelos and Pseudo-Jonathan adopt a different euhemeristic interpretation by translating 'sons of God' as 'sons of nobles' (בני רברביא) and Targum Neophyti translates 'sons of God' with 'sons of judges' (בני דיינא), which agrees with the assessment of Rabbi Simeon b. Yohai in Genesis Rabbah. This interpretation appears to be ubiquitous throughout rabbinic literature and influences later Jewish commentary tradition as well. For example, in his commentary on Genesis, Rashi interprets the phrase 'sons of God' as either 'sons of princes' (בשרים) בני) or 'sons of judges', (בני השופטים) and he gives various examples from Exodus (Exod 4:16 and 7:1) in order to demonstrate that the phrase 'God' (אלהים) can also mean 'authority' (מרות). Ps 82:1-2 is another example where אלהים with the plural verb agreement can mean 'judges'. The exceptions are Pirke de-Rabbi Eliezer 22 (8th or 9th century CE) and the Midrash on Shemhazai and Azael from Midrash Bereshit Rabbati (11th century CE) and the Chronicles of Yerahmeel (14th century CE). The distinctive move made by Christian euhemeristic interpretations was to equate the 'sons of God' with the 'sons of Seth', which I will discuss more below. For more on the Jewish interpretation of the Watcher myth in rabbinic literature and early Christianity, c.f. P. S. Alexander, “Targumim and Early Exegesis of 'Sons of God'," JJS 23 (1972): 60-77; Annette 
edge of Jewish interpretive strategies may have influenced some of his critique as well. ${ }^{12}$ Nevertheless, there may be a Christological reason for Ephrem's concern that is distinctive to his polemic. In Hymn 19 of Contra Haereses Ephrem contends that if angels and other non-human beings could have intercourse, then demons would copulate with women $a d$ nauseam and mitigate the uniqueness of the virgin birth (19.4-6). Instead, he claims it is impossible for women to give birth apart from men, which is a fact young women could easily verify. ${ }^{13}$ Ephrem's concern here seems to be the desire to protect the distinctiveness of Jesus by highlighting the miraculous nature of Jesus' birth. In other words, divinehuman pairings have to be unnatural for the virgin birth to be a miracle, and Jesus' birth needs to be miraculous to separate Jesus from the rest of humanity. Further, the belief in the possibility of such pairings outside of Jesus could lead to idolatry by making the children of these pairings divine, which was wildly popular in the Graeco-Roman world.

\section{Ephrem's rebuttal and re-telling of the Watchers myth}

If Mani's contention is incorrect, and women did not give birth to giants via angelic sexual relations, then Ephrem had to provide a counter interpretation, not only for the phenomenon of giants, but also for the Nephilim passage in Genesis 6:1-4. Although he does so in several places, his lengthiest rebuttal occurs in his Commentary on Genesis. ${ }^{14}$ In 6.3, after quoting the beginning of Genesis 6, Ephrem says,

He [Moses] again called the sons of Seth sons of God, those who, like the sons of Seth had been called "the righteous people of God." The beautiful daughters of men whom they saw were the daughters of Cain who adorned themselves and became a snare to the eyes (lit. "heart/mind") of the sons of Seth (6.3.1). ${ }^{15}$

Yoshiko Reed, Fallen Angels and the History of Judaism and Christianity: The Reception of Enochic Literature (Cambridge: Cambridge University Press, 2005), 122-59 and 213-18.

12. On the question of Ephrem's relationship to targumic interpretive traditions, see P. Féghali, 'Influence des Targums sur la pensée exégétique d'Ephrem," Orientalia Christiana Analecta 229 (1987): 71-82; Jeffrey Wickes, 'Ephrem's Interpretation of Genesis," St. Vladimir's Theological Quarterly 52 (2008): 45-65; Elena Narinskaya, Ephrem, a 'Jewish' Sage: A Comparison of the Exegetical Writings of St. Ephrem the Syrian and Jewish Traditions (Studia Traditionis Theologiae, 7; Turnhout: Brepols, 2010), 135-244. More generally, see Sebastian Brock, "Jewish Traditions in Syriac Sources," JJS 30 (1979): 212-32. For Christian influence, see Lucas Van Rompay, "Antiochene Biblical Interpretation: Greek and Syriac," in Book of Genesis in Jewish and Oriental Christian Interpretation: A Collection of Essays (ed. J. Fishman and L. Van Rompay; Louvian: Peeters, 1997), 103-12.

13. For Enoch and Enochic motifs in Ephrem, see Tryggve Kronholm, Motifs from Genesis 1-11 in the Genuine Hymns of Ephrem the Syrian: With Particular Reference to the Influence of Jewish Exegetical Tradition (CBOT 11; Lund: C.W.K Gleerup, 1978), 150-71.

14. Outside of the Commentary on Genesis and Contra Haereses, Ephrem briefly refers to the Watchers myth in Hymns on Paradise 1.11; Hymns on Nativity 1.22, 46-48; Hymns on Nisbis 1.4; and Hymns on Faith 46.8-9. In these texts, Ephrem primarily criticizes the equation of the 'sons of God' with the Watchers and suggests instead that this phrase in Genesis 6:1 refers to the "sons of Seth." See below as well as Kronholm, Motifs from Genesis, 166-68.

15. This translation of Ephrem's Commentary on Genesis and those that follow come from Edward G. Matthews and Joseph P. Amar, trans., St. Ephrem: The Syrian: Selected Prose Works 


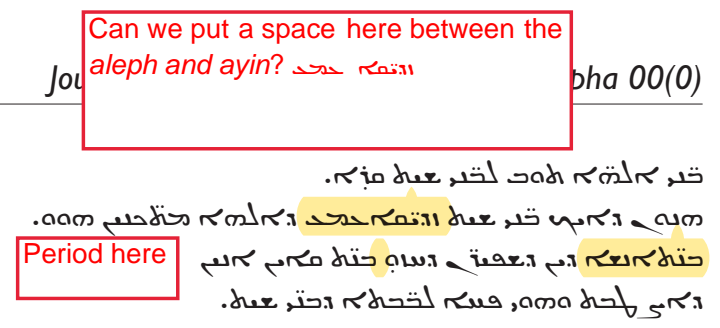

The main strategy Ephrem uses here is to equate the "sons of God" (تص, ملتهم) with the "sons of Seth" (تص, (כer). This is a strategy he employs in other works as well (Paradise 1.11; Nativity 1.46), and it is not unique to Ephrem. For example, in the Chronicles of Julius Africanus (c. 160-240 CE), he contends that there are two different interpretations of the phrase "sons of God" in Genesis: (1) angelic or (2) euhemeristic. Julius prefers the latter and is the earliest writer to compare the "sons of God" with the Sethites and the "daughters of Cain" with humanity (cf. Chronicles of Julius Africanus in Sync. 19.24-20.4). ${ }^{16}$ Nevertheless, Ephrem's elaboration of the intermingling of the sons of Seth with the daughters of Cain is quite distinctive. In 6.3.2, Ephrem claims,

The sons (lit. "house") of Cain were interested in neither the wealth nor the appearance of those women; they were seeking ploughmen for their lands that had been left uncultivated. Although this thing began because of the licentious and poor men - the licentious being driven by beauty and the poor being attracted to wealth - the entire tribe of Seth followed suit and was stirred to a frenzy over them. (Author's emphasis)

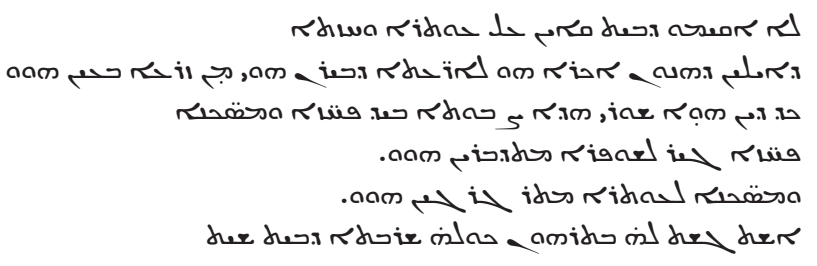

The distinctiveness of this interpretation for Ephrem is his emphasis on the poverty of the sons of Cain and the geography of the Sethites and Cainites. The Cainites live in the land of Nod on land that is cursed. In his commentary on Genesis 4:16, Ephrem interprets the land of Cain as a "land in which Cain wandered about in fear

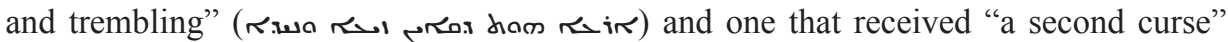
(ل) when God ordered the land to stop producing fruit for Cain and his

(FC 91; Washington: Catholic University of America Press, 1994), 134-35. For the Syriac text, see R. M. Tonneau, Sancti Ephraem Syri in Genesim et in Exodum Commentarri (CSCO 72; Louvain: Durbecq, 1965).

16. For the text of Julius Africanus, Iulius Africanus Chronographiae: The Extant Fragments (ed. Martin Wallraff; Berlin: de Gruyter, 2007), 48-51. The debate between angelic and euhemeristic interpretation of Gen 6:1 also exists in the textual tradition of Genesis. Although

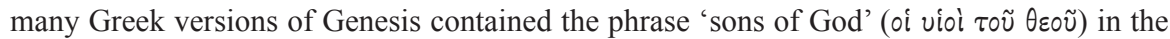
LXX as well as Jewish recensions such as Aquila and Symmachus, the variant 'angels of

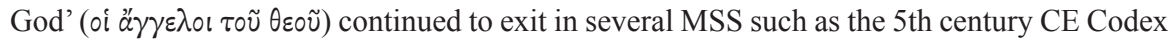
Alexandrinus. Interestingly, Symmachus (late $2 \mathrm{~d}$ /early $3 \mathrm{~d}$ century) offers the suggestion 'sons of the powerful' (oi vioi $\tau \tilde{\omega} \nu \delta u v a \sigma \tau \varepsilon v o ́ v \tau \omega \nu=$ אִיל which agrees with the suggestions of the rabbis. See Reed, Fallen Angels, 216-18. 
descendants when they tilled it. ${ }^{17}$ Because of this second curse, the land produced

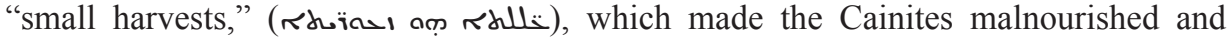
without strength (6.5.1). The Sethites, on the other hand, lived on a verdant mountain close to Paradise. As a result they were healthy and strong (cf. 6.5.1 and Paradise 1.10-11). ${ }^{18}$ If the Sethites sired children with the Cainites, then the Cainites would

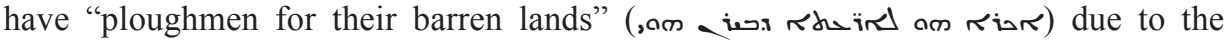
strength and stature of the Sethites. Thus, it is the stature of the "powerful sons of Seth"

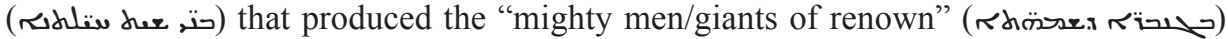
which is Ephrem's explanation for how giants came to be born from the small race of Cainites (cf. 6.5.2-6.6.1). ${ }^{19}$

The consequence of this action affects the Sethite women as well. In 6.3.3, Ephrem lays out their downward spiral:

Because the sons of Seth were going into the daughters of Cain, they turned away from their first wives whom they had previously taken. Then these wives, too, disdained their own continence [lit. "their own preservation"] and now, because of their husbands, quickly began to abandon their modesty, which up until that time they had preserved for their husband's sake [or "alongside their husbands"].

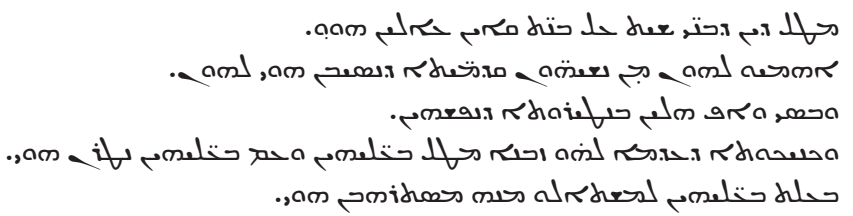

Unlike the well-adorned Cainite women, the Sethite women emphasized modesty, which they guarded along with the preservation of their purity until their husbands abandoned them. Either following their husband's lead or as an act of revenge, now the Sethite women

17. This interpretation of the land of Nod is also close to the Targumim. Kronholm, Motifs from Genesis, p. 168, n. 49. The geographical separation between Sethites and Cainites is ubiquitous throughout Ephrem's work and influential on latter Syriac commentators and chronicles. See Paradise 1.11 above.

18. The location of Eden on a mountain occurs in Ezek 28:12-19 and may have influenced Ephrem here. Also, cf. Isa 14:18 and Ps 48:1-2. As Katheryn Pfisterer Darr states, "In Israelite religious imagination the Temple Mount, God's holy mountain, and Eden are frequently conjoined." Katheryn Pfisterer Darr, "The Book of Ezekiel," in The New Interpreter's Bible (ed. L. Keck et al.; Nashville: Abingdon, 2001), VI, 1393. Similarly, Jubilees 4:26 seems to imply the garden of Eden is one of God's holy mountains like Mount Sinai and Mount Zion. Also, cf. Jub. 8:19; 1 En. 24:3-4; 25:4-5. This Jewish interpretive tradition may have influenced Ephrem's reading as well. Interestingly, Tg. Ps.-J 2:15 describes God as creating Adam on a mountain and removing Adam from it to place him in Eden, which contrasts with the Eden-mountain tradition discussed here.

19. In Syriac بلحتح can mean both "mighty men" or "giants." Surprisingly, even though Ephrem calls the offspring of the Cainites and Sethites 'giants' he still claims they were smaller in stature than the pure Sethites. The smaller and weaker stature of the Cainites (who were mostly women) truncated the giants as well. Kronholm, Motifs from Genesis, 171, 210-14. 
also set aside their commitment to virginity and adorned themselves with jewelry similar to the daughters of Cain. By eschewing their modesty, the Sethite women put themselves on par with the Cainite women so that all flesh became corrupted (wרل).

Ephrem also refers to the joining of the Sethites and Cainites in his commentary on Gen 4:18-24. In 4.3.2-3, Ephrem refers to Lamech's killing of Cain as part of his solution to force the Sethites to intermingle with his descendants so his line would not be cut off. ${ }^{20}$ The second phase of Lamech's plan was to adorn his daughters and have them seduce the sons of Seth:

Their daughters then adorned themselves for the sons of Seth, and Jabal enticed them with the choice portions of the flesh of animals and Jubal captivated them with the sweet sound of his lyres. Then the sons of Seth yielded and, because of these things, they forgot that noble covenant that had been established by their father and they came down from their place, for it was higher than where the descendants of Cain dwelt. Thus, Lamech, by his cunning ploys, intermarried those tribes. ${ }^{21}$

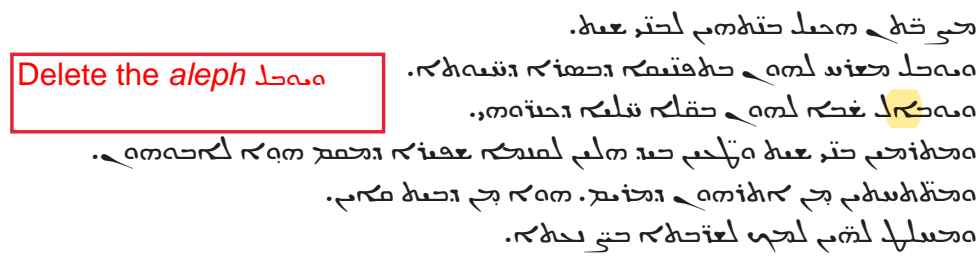

Although Ephrem ignores the theme of astronomical knowledge, forbidden knowledge may still play a role here. Instead of the creation of jewelry being forbidden knowledge an angel provides, now it is the jewelry by the daughters of Cain that tempts the sons of Seth to inquire about hidden knowledge. Since God gave antediluvian humans only plants to eat, presumably eating meat was sinful, and the combination of singing, musical instruments, and jewelry was often thought of as a catalyst to debauchery. Elsewhere Ephrem

20. Many Syriac and Ethiopic commentators and stories, likely influenced by the Cave of Treasure tradition, suggest that Lamech killed Cain on accident, having mistaken him for an animal. Nevertheless, Isho 'dad of Merv (c. $850 \mathrm{CE}$ ), quoting Henana (d. $610 \mathrm{CE}$ ) agrees with Ephrem's assessment that Lamech intentionally murdered Cain in order to ameliorate the curse of Cain and end the separation between the children of Cain and the children of Seth. Interestingly, one finds both versions in the Genesis commentary of Meherka Dengel (17th cent.) contained in EMML 2101. This Ge'ez commentary also cites Henana as its source, and appears to be a translation of Ibn al-Tayyib's Genesis commentary in The Paradise of Christianity, which likewise cites Henana as its source (EMML 2101, f.74r, col. 3, ln. 18-f. $75 \mathrm{v}$, col. 1, 1n. 30). For the relationship between Meherka Dengel and Ibn al-Ṭayyib as well as al-Tayyib's connection to Syriac sources, see n. 50 below. For the Genesis portion of al-Ṭayyib's commentary, see J. C. J. Sanders, Commentaire sur la Genèse (CSCO, 274-75; Louvain: Peeters, 1967), 44-45 [42-43]. For the Lamech tradition in Christian literature, see A. F. J. Klijn, Seth in Jewish, Christian, and Gnostic Literature (NovTSup, 45; Leiden: Brill, 1977), 67-77.

21. Ephrem also mentions Lamech's plan in Hymns De Ieiunio 2.2. See Kronholm, Motifs from Genesis, 169. 
describes Cain's descendants, Jubal and Tubal-Cain, as specifically inventing lyres and cymbals along with melodies to go along with the adornment of Cain's daughters as a means of trapping the Sethites (Ieiun 2.2). The sin of the Sethites may simply have been leaving their mountainous homes close to Paradise, but the means by which the Cainites entice the Sethites corresponds to the forbidden acts of knowledge in the Asael stream of the Watchers myth and forbidden acts of knowledge in other Syriac commentators. ${ }^{22}$ Furthermore, unlike other Syriac commentators on Genesis (e.g. Isho'dad of Merv), Ephrem only denies the carnivorous and cannibalistic aspects of the giants, he does not reject their creation altogether, even if he means by this term "large people" and not "creatures who were 3000 cubits tall"!23 In other words, despite Ephrem's attempt at repressing the Watchers myth, major elements of it have survived in his re-telling. It is unclear why these aspects of the Watchers myth remain in Ephrem's commentary despite his hatred of the original. Because the Watchers myth and Ephrem are both explicating Genesis 6:1-4, it is possible that Ephrem retains the parts of the Watchers myth he thinks are relevant to Genesis and rejects the rest. In other words, they both had the same source text. Another possibility is that Ephrem is familiar with different interpretive strategies of this story in Christian (sons of God = sons of Seth) and Jewish communities (garden = God's mountain) and chooses to combine them while rejecting the aspects of the Watchers myth that could encourage Manicheanism. The latter seems the most likely. Despite some overlaps with the Watchers myth and other interpretations of it, Ephrem has several distinctive additions as well. The dichotomies between poverty and wealth and mountains and valleys as well as his emphasis on modesty and adornment are significant themes throughout Ephrem's writings. His expounding of these themes in other places should provide a clue to the importance of their placement in Ephrem's re-telling of the Watchers myth.

\section{The Watchers myth and Ephrem's angelology}

Striking parallels become apparent when one examines Ephrem's angelology. For Ephrem, angels had a different body than humans altogether, which is one reason copulating with humans would have been impossible (Paradise 6:24.1). ${ }^{24}$ Instead of corporeal

22. The teaching of esoteric knowledge to the Sethites is even more apparent in the commentary of Isho dad of Merv (c. 850) who claims the three children of Lamech corrupted the Sethites using knowledge as a means of seduction. Klijn, Seth in Jewish, Christian, and Gnostic Literature, 75-76. Also, see the Cave of Treasures 11:1-12;21:8-15 which specifically connects music to demons and blames the creation of musical instruments for the Flood. For more on the Cave of Treasures and Ephrem, see below.

23. For Theodore bar Konai, Isho 'dad, and an anonymous Genesis commentary from Diyarbakir, the phrase 'giants' refers to those giant in iniquity and is not a reference to those large in stature. Klijn, Seth in Jewish Christian, 75-76.

24. Testament of Reuben 5.6 also avoids the problem of actual intercourse between humans and angels by having the act occur in the mind. It is the women's mental fixation on the stature of angels - who were as tall as the sky - while having intercourse with their husbands that give birth to giants. The correspondence between visual stimuli and gestation is present in numerous Greek and Latin gynecological texts as well as some Jewish and Christian texts. Cf. Ra'anan Boustan, "Rabbi Ishmael's Miraculous Conception: Jewish Redemption History in Anti-Christian Polemic," in The Ways that Never Parted: Jews and Christians in Late 
bodies, angels have bodies of fire and spirit (Faith 10:9), which is an assessment one also finds in Homily 8.18 of the Pseudo-Clementine literature. ${ }^{25}$ As with much of Ephrem's terminology "fire and spirit" is also symbolic and can refer to "hidden, spiritual reality" in general. ${ }^{26}$ Like God, the true nature of angels can only be "perceived by the "luminous eye." 27 This is a kind of "inner eye" that allows one to see the spiritual realm behind reality and read correctly "God's types and symbols in Scripture and Nature." 28 Hence, those with the "luminous eye" to perceive the true nature of angels would never assign sexuality to the angelic body. The angelic body was also a virgin body, which is another key feature of Ephrem's angelology. The virginity of angels is undoubtedly influenced by Jesus' statement that Christians at the resurrection will not be concerned with marriage, making them like angels (Mt. 22:30; Mk. 12:25; Lk. 20:36) as well as the relationship between the Syriac term for angels-Watchers (حن) , and the parable of the Wise and Foolish Virgins in Matthew 25. Since the wise virgins are those who are attentive to the Bridegroom, the name of the angels themselves points to highest goal of Christian life. ${ }^{29}$ As R. M. M. Tuschling contends, "attentiveness, immortality, purity, wakefulness are all held together in the one word i..." "30 Finally, another distinctive feature of angels is their liturgical function. Angels are in constant praise before God, but because right knowledge about God and God's ineffability are important for Ephrem, the highest form of angelic praise is silence (Faith 4.1). ${ }^{31}$

Out of these angelic features, virginity may have been the most important. One cannot overstate how central virginity was for Syriac Christianity even before the influence of the Desert Fathers. The key monastic term in Ephrem's time period was r.ue ("single or simple"), which referred both to virgins (حصa) and married people who renounced

Antiquity and the Early Middle Ages (ed. Adam H. Becker and Annette Yoshiko Reed; TSAJ, 95; Tübingen: Mohr Siebeck, 2003), 315-17. See Galen, De theriaca, 11; Soranus, Gyn.1.39; Caelius Aurelianus, Gyn. 1.50. For this idea in Jewish and Christian texts, see Num. Rab. 9.34 and Augustine, De Trinitate 2.5. Also, cf. the Lamech tradition in Genesis Apocryphon and 1 Enoch 106-7 and the analysis of this material in Loren T. Stuckenbruck, "The Lamech Narrative in the Genesis Apocryphon (1QapGen) and Birth of Noah (4QEnoche ar): A Tradition-Historical Study," in Ameraica Qumranica: Proceedings of the Conference on the Aramaic Texts from Qumran in Aixen-Provence 30 June-2 July 2008 (STDJ, 94; Leiden: Brill 2010), 253-75.

25. Presumably Ephrem's equation of angels with fire comes from the seraphim in Isaiah 6 or the description of fire with cherubim in Ezekiel 1. Angels having bodies of fire also allows Ephrem to accentuate the impossibility of mixing angelic bodies with human ones. For angels in Ephrem, see Winfrid Cramer, Die Engelvorstellungen bei Ephräm dem Syrer (Orientalia Christiana Analecta, 173; Roma: Pont. Institutum Orientalium studiorum, 1965).

26. R. M. M. Tuschling, Angels and Orthodoxy: A Study in Their Development in Syria and Palestine from the Qumran Texts to Ephrem the Syrian (Tübingen: Mohr Siebeck, 2007), 173.

27. Tuschling, Angels and Orthodoxy, 173.

28. Sebastian Brock, The Luminous Eye: The Spiritual World Vision of Saint Ephrem the Syrian (Rome: C. I. I. S., 1985), 77.

29. Cf. Brock, Luminous Eye, 140; idem, St. Ephrem the Syrian: Hymns on Paradise (Crestwood: St. Vladimir's Seminary, 1990), 21.

30. Tuschling, Angels and Orthodoxy, 173.

31. Brock, Luminous Eye, 79. 
sexual intercourse (م.. (م) and was also a key term for Christ. ${ }^{32}$ Similarly, as early as Aphrahat an ideal Syriac Christian inspired toward classification as a حص,/حud مesى, which is a phrase notoriously difficult to translate. Although this phrase often denotes an ascetic elite it can also refer to all Syriac Christians. ${ }^{33}$ One interpretation of how one achieved this position was by making "a vow, either of bthuluta "virginity'," or of qaddishuta "sexual abstinence in marriage" - "a vow which was probably made at the same time as baptism when this took place in adulthood." 34 In other words, "the bnay qyama would appear to be a group of people who led some form of consecrated life and whose common denominator was probably the fact that they had all undertaken a vow of chastity." 35 Celibacy was taken for granted as the ideal, even if only the elect few actually practiced it. Virginity was necessary for two reasons. First, an ideal Christian was the bride of Christ and Christ was the Bridegroom (几hw). This was a favorite title among Syriac ascetics, but it was also a key metaphor for baptism. At baptism, one married Christ and received the two-fold crown traditionally received by brides on their wedding day (Epiphany 11.1). ${ }^{36}$ Second, since Adam and Eve were both virgins in Paradise, those who wished to re-enter eschatological Paradise had to remain sexually abstinent. ${ }^{37}$

The relationship between this ideal and angels is obvious from Ephrem's Hymns on Virginity. In 1.8, Ephrem calls virginity the "dear friend of the Watchers" and contends that when it "takes flight, the companion of demons enters: desire, which is the hatred of virginity." 38 Furthermore, Ephrem calls angels a hermit's closest friend (S. Erem 161-68). ${ }^{39}$ Because angels exist in a state without marriage, they are the archetype for virginity and as such the paradigm for the ideal Christian. Thus, the Old Syriac of Luke 20:35-36 claims that those worthy of the coming kingdom and of resurrection do not marry, nor can they die, "for they have been

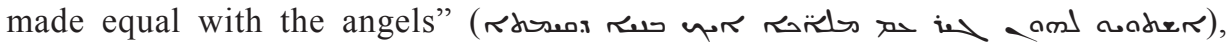
which is a much stronger equation of the celibate with the angels than the Peshitta, "for they are like angels" (i _ ritual takes this metaphor a step further. In baptism, Ephrem claims that Christians "put on the Watchers in the waters" (Epiphany 4:8) and at the Eucharist, Christians

32. Brock, Hymns on Paradise, 26.

33. Brock, Hymns on Paradise, 135.

34. The two most common translations argue that حس, refers to 'sons/daughters of the covenant' or 'sons/daughters of the resurrection'. See R. A. Kitchen, "Bnay Qyāmā, Bnāt Qyāmā," in GEDSH (ed. Sebastian Brock et al.; Piscataway: Gogias, 2011), 84-85.

35. Brock, Hymns on Paradise, 135. What appears then to separate the proto-monastic focus of early Syriac Christianity from the Desert Fathers is that Syriac asceticism was more of "an urban or village phenomenon." Brock, Hymns on Paradise, 26. It was also highly individualistic and lacked the communal focus of Egyptian monasticism. Robert Murray, Symbols of Church And Kingdom, 155-57.

36. Murray, Symbols of Church and Kingdom, 132, 140-42.

37. Brock, Hymns on Paradise, 25-33.

38. Katherine E. McVey, Ephrem the Syrian: Hymns on the Nativity Hymns against Julian, Hymns on Virginity and on the Symbols of the Land. The Classics of Western Spirituality (New York: Paulist Press, 1989), 263.

39. Tuschling, Angels and Orthodoxy, 164-65.

40. Brock, Luminous Eye, 140. 
become angelic beings "by means of Fire and Spirit" (Faith 10:9). Thus, Ephrem sees ritual as transforming all Christians into angelic beings and helping them achieve the ascetic ideal of wakefulness, singleness, and chastity. ${ }^{41}$ Finally, for Ephrem, angels are role models for right belief and practice. ${ }^{42}$ Unlike Mani, they do not push the boundaries of what can be known and do not pry into divine mysteries (P. Ref. 1). ${ }^{43}$ Thus, as mentioned above, the highest praise of angels is silence. Like the angels, the ideal Christian moves from the silence of ingratitude to vocal praise and from vocal praise to the angelic praise of silence before God's ineffable Being. ${ }^{44}$ Silent praise enhances the luminous eye (حhar r a faith, which is able to perceive the symbols God has placed in the Bible and nature without making them lose their paradoxical nature by truncating the divine mysteries. ${ }^{45}$

Having established the corollary between Ephrem's angelology and ecclesiology, the influence of Ephrem's angelology on his re-telling on Genesis 6:1-4 becomes quite clear. First, regarding the euhemeristic interpretation of angels, Ephrem's use of this interpretive strategy subtly attempts to provide the "right" interpretation of angels and mitigates against the angelic interpretation of Mani and others, whom Ephrem believes pushes the boundaries of knowledge. ${ }^{46}$ In other words, it is the "luminous eye" that sees the symbolic relationship between the children of God and the children of Seth and it is the prideful eye that attempts to pry into the divine mysteries of the heavenly realms. As mentioned above, astrology and the divinity of Christ seems to be the main concern here. Furthermore, the enticement of the Sethites by the inventions of Jabal and Jubal also plays into the theme of forbidden knowledge. Although Ephrem ignores the astronomical component in the Watchers myth, he still is concerned with the allurement of knowledge beyond what is necessary and the problem of enhanced beauty through adornment.

Second, although Ephrem's re-telling of Genesis 6:1-4 does not mention the ideal of virginity directly, it does emphasize the problem of sexual depravity along with the temptations of gluttony, greed, and avarice. One of the distinctive features of the Sethites before their intermingling with the Cainites was their modesty (حسمra), which husbands and wives guarded together until the temptation caused by the daughters of Cain. Thus, although the Sethites were married, Ephrem depicts them as existing in a state of qaddishuta (that is, celibacy) until they desired the daughters of Cain. The danger of the Cainite women represents the danger of sexuality in

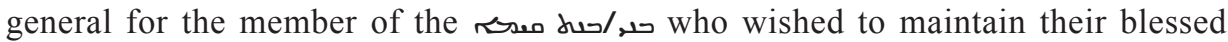

41. Brock, Luminous Eye, 140. Also see Murray, Symbols of Church and Kingdom, 14, 154-57.

42. Tuschling, Angels and Orthodoxy, 175.

43. Tuschling, Angels and Orthodoxy, 175. Also, see David Bundy, "Ephrem's Critique of Mani: The Limits of Knowledge and the Nature of Language," in Gnosticisme et monde hellénistique (ed. J. Ries with Y. Janssens and J. M. Sevrin; Louvain: Institut Orientaliste de Louvain, 1980), 289-98.

44. Brock, Luminous Eye, 79. For more on the dichotomy between silence and praise and the limits of knowledge in Ephrem, see Kees Den Biesen, Simple and Bold: Ephrem's Art of Symbolic Thought (Piscataway: Gorgias, 2006), 147-277.

45. Brock, Luminous Eye, 79. For Ephrem, symbols are mirrors of truth that reflect harmony between Creator and created only in their interrelation. Bundy, "Ephrem's Critique of Mani," 295.

46. Bundy, "Ephrem's Critique of Mani," 292. 
state. As with the Sethites, a little sex brings about the downfall of the entire community and could potentially bring about the corruption (vבר (v) of society as a whole. However, it was not simply the sexuality of the daughters of Cain that tempted the

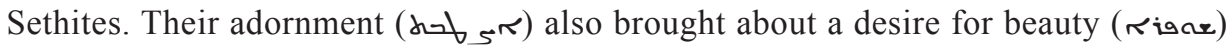
and wealth (حido). In this way, the "fall" of the Sethites is similar to Ephrem's depiction of the Fall of Adam and Eve who also lost their blessed state due to avarice (Rhow; Genesis 2.16.2). ${ }^{47}$ Inversely, if the Sethites had not intermingled with the Cainites, they would not have lost their powerful and large bodies and would have maintained their abode on the mountain on the border of Paradise. This location gave the Sethites a position similar to the angels. Having lost their mountainous abode, the Syriac Christian community could now only gain proximity to Paradise through virginity and through Christ.

\section{Ephrem in the andemta tradition?}

The addition of monastic and angelic components to the Sethite interpretation of the Watchers myth is also present in the Ethiopian commentary tradition known as the andemta, which flourished in the Gondarine period in the seventeenth-century $\mathrm{CE}$ in Ethiopia but is a product of much older traditions. The andemta of Genesis 6:2 explains the intercourse between the "sons of God" and the "daughters of Cain" in the following manner: ${ }^{48}$

Tarik: If one enquires about this, these sons of Seth vowed saying, "We live a cenobitic life in the Holy Mountain, keeping ourselves away from women and having no marital relationship, glorying our Creator like angels saying, 'Holy, Holy, Holy'.” Temporarily, they kept themselves away from women, had no marital relations so that the virtue of the angels and the sin of the evil spirits be revealed to them for they stayed in the Holy Mountain glorifying their Creator saying: Holy, Holy, Holy. One day, they saw the sons of Cain, both men and women, with aprons lashed around their waist; taking their genitals out and flirting by jumping one over the other like mare and young donkey and their bodily desires were highly aroused. Then, they said one to the other, "come and let us go down and take one for each of us from the sons of men and do as we see fit," and so they went down and remained there forever. Andemta: they went down for other purpose[s] and remained there forever as a monk who go[es] out of his cell to look for a monastic asset remain[s] in the world forever. ${ }^{49}$

\section{Gen 4:22}

47. For Ephrem, Adam and Eve's avarice was so strong that they would have taken from the Tree of Knowledge eventually with or without the serpent's trickery.

48. There is another, more elaborate version of this story in the andemta commentary on Psalm 82, which places blame on a Nuhem, who is identified as Naamah mentioned in Gen. 4.22, rather than Semyaza (Semihazah). A similar story is also found in the andemta of 1 Enoch. Both andemtas equate the sons of God with the sons of Seth but incorporate Enochic tradition throughout, which one also finds in the Chronicle tradition. See Ralph Lee, "The Ethiopic 'Andəmta' Commentary on Ethiopic Enoch 2 (1 Enoch 6-9)," JSP 23 (2014): 179-200. One also finds a combination of Sethite and Enochic traditions in the commentary on Genesis 6 by Meherka Dengel (EMML 2101, f.75r, col. 3, ln. 5-f. 76v, col. 1, 1n. 2).

49. Mersha Alehegne, The Ethiopian Commentary on the Book of Genesis: Critical Edition and Translation (AeF 73; Wiesbaden: Otto Harrassowitz, 2011), 98, 434. 


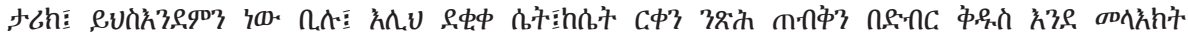
中.

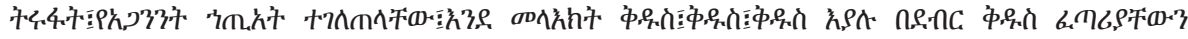

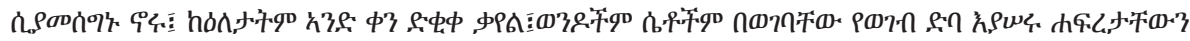
久 え

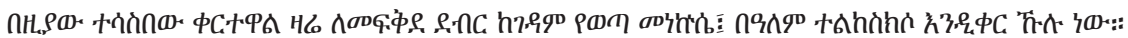

The theme running throughout this tarik is holiness ( $\$$. my purposes, is both the presence of the Sethites' mountainous abode as well as their

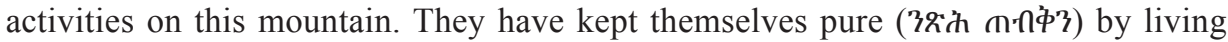

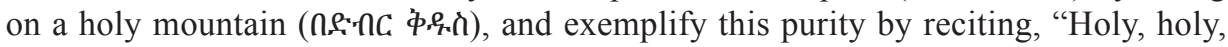

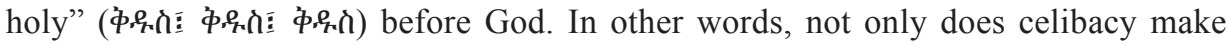
the Sethites like the angels, but it allows them to participate in angelic praise through the recitation of the Sanctus. Through sexual intercourse, the Sethites can no longer engage in these activities, and instead, become like a monk who loses access to his monastic abode in the mountains due to pollution from the world.

Although Ephrem was quite popular in the Ethiopian tradition, as seen particularly in his attribution to the hymns to Mary (Weddāse Māryām), it is much more likely that motifs from Syriac exegetical traditions were introduced into the andemta through Ge 'ez commentaries and translations of Syriac and Arabic works. This is a process of transmission that Aaron Butts has already demonstrated in several places. ${ }^{50}$ Nevertheless, the strongest connection between

50. Along with several Aramaic or Syriac loanwords in Ge'ez (e.g., hāymānot), Syriac influence on Ge'ez biblical names and texts (e.g., the name Walda Yonā as a translation of Bar do Yōnā

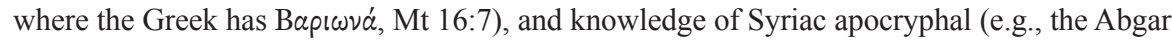
legend) and hagiographic literature (e.g., Ephrem's 15th Hamle), there is a great deal of evidence for the influence of Syriac commentary tradition on Ge'ez and Amharic, which was often mediated through Arabic sources, such as the work of Ibn al-Tayyib (d. $1043 \mathrm{CE}$ ). For example, Aaron Butts has demonstrated that the Ethiopic commentary on Genesis by Meherka Dengel contained in EMML 2101 utilized the Ethiopic translation (Bibl. Nat. Eth. d'Abbadie 28) of the Arabic commentary of Ibn al-Ṭayyib (ms. Vatican Arb. 37), which, in turn, utilized the Genesis commentary of Isho 'dad of Merv and the Scholion by Theodore bar Konai. Cf. Aaron M. Butts, "In Search of Sources for Ibn al-Tayyib's The Paradise of Christianity: Theodore Bar Koni's Scholion," JCSSS 14 (2014): 3-29; idem, "Embellished with Gold: The Ethiopic Reception of Syriac Biblical Exegesis," Oriens Christianus 97 (2013-14): 137-59. W. Witakowski , "Syrian Influences in Ethiopian Culture," OrSu (ed. Siegbert Uhlig) 38-39 (1989-90): 192-202; idem, "Syrian influences in Ethiopia," in EAe (Wiesbaden: Harrassowitz, 2010), 4: 782-84. Aaron M. Butts, "Ethiopic Christianity, Syriac Contacts With." in GEDSH (ed. Sebastian Brock et al.; Piscataway: Gogias, 2011), 148-53. (ed. Siegbert Uhlin;

Although Butts utilizes the Joseph narrative in his work, one Wiesbaden; Harrassowitz, argument regarding the exegetical tradition of Genesis 6:2. In G 2010)

and Isho 'dad of Merv refer to the children of God as the 'children of rulers', which Isho 'dad says he is getting from Symacchus, they both cite Ps. 82:1 as an example of using the nomenclature 'god' for humans, and they both minimize the term 'giant', by making the term a reference to 'giants in iniquity and impiety' rather than a reference to physical stature. Thus regarding Gen. 6:2, Butts point also stands: "Ibn al-Ṭayyib incorporates each of these traditions from Isho dad of Merv into his commentary [and] even retains the order (emphasis mine) of presentation found in Isho dad of Merv." Similarly, Isho dad uses the work of 
Syriac, Ge 'ez, and Amharic regarding Genesis 6:2 comes through apocryphal tales associated with Seth, in particular the sixth-century CE Syriac work, the Cave of Treasures. Interestingly, the Cave of Treasures was traditionally attributed to Ephrem (see the colophon in B.M. Add. 25875) and alludes to Ephrem's commentary in several places. In this work, Seth and the Sethites replace the fallen angels as the true sons of God due to their purity and are given residence on a holy mountain near Eden. On this mountain, they not only hear angelic singing but participate in it and thus become "angelic people" $\left(C T\right.$ 7:5, 11:12). ${ }^{51}$ When the music and debauchery of the daughters of Cain tempt the sons of Seth, they fall from the holy mountain and are unable to return (CT 12:7-21). Although, the Cave of Treasures is the first text to make explicit the monastic and angelic interpretation of the Sethites, one sees similar themes in the Ge'ez works the Conflict of Adam and Eve (sixth century) and the Qalementos (fourteenth century), the latter of which is a conscious re-interpretation of the Cave of Treasures. Out of these works, the Qalementos is the only work where the Sethites not only participate in angelic praise, but they do so with the words from Isaiah 6:3, exclaiming, "Holy, holy, holy." ${ }^{52}$ Because the compilers of the andemta would have known the Qalementos, it is possible that the andemta of Genesis 6:2 is primarily utilizing its re-telling of the Cave of Treasure tradition. Thus, instead of the andemta borrowing from Ephrem directly, it is much more likely that the compilers of the andemta utilized a tradition beginning with the Cave of Treasures that first become part of Ethiopian tradition in the Conflict of Adam and Eve and the Qalementos. ${ }^{53}$ The andemta incorporated and elaborated on this tradition so that the fall of the Sethites could function as a cautionary tale for the Ethiopian monks who memorized and preserved the andemta tradition, which is particularly fascinating in light of the fact that the Ethiopian tradition freely incorporated the Enochic Watchers myth in its liturgy. For my purposes, the andemta's accentuation

Ephrem and Theodore bar Konai and many of the exegetical traditions in Isho dad's commentary have their basis in Ephrem's exegesis.

51. For the Cave of Treasures, see Su-Min Ri, La Caverne des Trésors: Les deux recensions syriaques (CSCO, 486-87/Scriptores Syri, 207-208; Louvain: Peeters, 1987); Alexander Toepel, "The Cave of Treasures: A New Translation and Introduction," in Old Testament Pseudepigrapha: More Noncanonical Scriptures (ed. Richard Bauckham et al.; Grand Rapids: Eerdmans, 2013), I, 531-84; Sergey Minov, "The Syriac Cave of Treasures: A Reappraisal," Hugoye: Journal of Syriac Studies 20.1 (2016): 129-229. For more on angelic motifs and monasticism in the Cave of Treasures, see Jason Scully, "The Exaltation of Seth and Nazirite Asceticism in the Cave of Treasures," VC 68 (2014): 310-28. Also, cf. Jürgen Tubach, "Seth and the Sethites in Early Syriac Literature," and Gerard P. Luttikhuizen, "Gnostic Ideas about Eve's Children and the Salvation of Humanity," in Eve's Children: The Biblical Stories Retold and Interpreted in Jewish and Christian Traditions (ed. Gerard P. Luttikhuizen; Leiden: Brill, 2003), 187-20 and 203-17.

Finally, though it is possible that the mountainous abode is something that the Syriac tradition received from the Chronicle tradition as seen by its usage in the Chronicles of Panodorus and Annianus in the 5th century CE, Ephrem is the first to explicitly mention the Sethites home on a mountain.

52. For the Qalementos, see S.Grébaut, "Traduction du Qalémentos (Littérature éthiopienne pseudo-clémentine 3)," ROC 16 (1911): 72-84, 167-75, 225-33; 17 (1912): 16-31, 133-44, 244-52, 337-46; 18 (1913): 69-78; 19 (-1914): 324-30; 20 (1915-17): 33-37, 424-30; 21 (1918-19): 246-52; 22 (1920-21): 22-28, 113-17, 395-400; 26 (1927-28): 22-31.

53. For more on the Qalementos and its correspondence to the Arabic Kitāb al-magāll, see Alessandro Bausi, "Qälemnțos," in EAe (Wiesbaden: Harrassowitz, 2010), 251-53. 
of the Sethites' loss of their angelic status and monastic abode is a salient illustration that makes explicit the connection between the Sethites, angels, and monasticism that I have argued is only implicit in Ephrem.

\section{Conclusion}

In his analysis of the Mekilta, Daniel Boyarin argues that midrash often "makes manifest the hidden dimensions of that mythic intertext by gathering together these fragments of allusions and figural language [of myth and earlier 'pagan' material] and reinscribing them into narratives." ${ }^{54}$ In this regard, Ephrem's re-telling of the Watcher myth also represents a midrashic "return of the repressed." 55 Although he tries to suppress the Watchers myth, particularly its angelic components, Ephrem still contains references to adornment, esoteric knowledge, and giants, which are predominant in the mythological version of Watchers. He adds new elements as well by making the Cainites and Sethites live in different geographical locations and by giving them different diets and body structures. These dichotomies, along with Lamech's plan of adornment, allow Ephrem to emphasize avarice, gluttony, modesty, and chastity. These distinctive components appear to be influenced by Ephrem's emphasis on virginity and monasticism for all Christians, which are components that become much more elaborate in other Sethian interpretations of Genesis 6:2, particularly in Syriac, Arabic, and Ethiopic commentaries and apocryphal stories influenced by the sixth-century work, Cave of Treasures. By embodying these ideals, the Sethites becomes like angels, which are, in turn, the archetype of Christian virginity. This direct correlation between monastic ideals and angelology permeates the re-telling of the Watchers myth in Syriac and Ethiopic traditions. In attempting to bowdlerize the angelic interpretation of Genesis 6, the Syriac and Ethiopian traditions support angelic readings of Genesis 6 of a different kind.

\section{Author's note}

I would like to dedicate this article to Jeff Childers at Abilene Christian University who was my first rials and a great advocate for Syriac studies.

\section{Declaration of conflicting interests}

The author(s) declared no potential conflicts of interest with respect to the research, authorship, and/or publication of this article.

\section{Funding}

The author(s) received no financial support for the research, authorship, and/or publication of this article.

\section{Author biography} program in 2012.

David A Skelton received his PhD in Religions of Western Antiquity from Florida State in 2012. He most recently served as a Visiting Assistant Professor of Religion in Pepperdine University and is currently an independent scholar.

54. Daniel Boyarin, Intertextuality and the Reading of Midrash (Bloomington: Indiana University Press, 1990), 94.

55. This phrase comes from Rachel Adelman's book, The Return of the Repressed: Pirqe deRabbi Eliezer and the Pseudepigrapha (Leiden: Brill, 2009), 20, 54. 